\title{
DIGITAL TRANSPARENCY IN THE PUBLIC SECTOR - CASE STUDY CZECH REPUBLIC
}

\author{
Hana Mohelská, Marcela Sokolová
}

\section{Introduction}

Transparency in the public sector is still a topical issue in contemporary society. The concept of transparency has been one of the most discussed topics within good governance over the last 20 years, and therefore it at-tracts interest for academic study. The consequences of transparency and also the circumstances that trigger transparency, are studied intensively. The attention given to the concept of transparency appears to have in-creased, mainly due to the spread of the Internet; hence, this paper particularly focuses on transparency enabled by the Internet (Sičáková-Beblavá, Kollárik, \& Sloboda, 2016).

In the Czech Republic, this is evidenced by the adoption of Act No. 340/2015 Coll. On the register of con-tracts, effective from 1st of July 2016, which imposes public contracts to be published in the register of con-tracts. The transparency of information provided reflects confidence in decision-making by a group of authorised or elected people. The practices of the elected bodies that respect transparent governance and the use of public funds should belong to the foundations of a modern democratic society. In modern society, interlinked concepts related to transparency and governance have been defined:

- Public-sector transparency,

- Government transparency or Organisational transparency.

How to provide (Sičáková-Beblavá et al., 2016) here transparency is therefore perceived as an essential aspect of rationality, progress and good governance (Florini, 2007), and "as a conduct of public affairs in the open or otherwise subject to public scrutiny" (Birkinshaw, 2010). Piotrowski and Van Ryzin (2007) stress the role of transparency in discovering what is going on inside government, and Strathern (2000) emphasises the proposition that "if procedures and methods are open to scrutiny, then the organisation is open to critique and ultimately to improvement." Prat (2006) stresses the aspects of controlling transparency within organisations using principal - agent model. Here, transparency is an instrument in the hands of principal where it is used to make sure that the agent is acting in line with principal through the delegation of power (Prat, 2006). Within the given model transparency is an instrument in the hands of the principal, who can use it to make sure that the agent - acting on the behalf of the principal via delegation of the power doesn't promote their own interests instead of those of the principal. When information asymmetry is to the agent's advantage, this may lead to governance abuse and failures. Such problems are believed to be remedied by transparency (Bannister \& Connolly, 2011).

Cases of corruption, embezzlement, theft and fraud, abuse of discretion, favouritism, nepotism, clientelism, and a government's abuse of power have led to a growing demand from society to access public information. In response to this demand, governments have been forced to be more transparent in their activities conduct. The information transparency index $(\mathrm{TI})$ may be conditioned by local governments economic and political characteristics affecting the information provided (Araujo \& Tejedo-Romero, 2016; Bennis, 2013).

Canares (2016) argues that the use of ICT can make more transparent and accountable revenue generation systems possible to benefit both government and taxpayers. However, these results are differentiated depending on the political leadership levels, the nature of articulation of demand for ICT use, the ratio of benefit against cost, and the technical skills and resources availability at sub-national level. It is within this context that an eco-system analysis 
is argued to be useful in analysing how ICT can be adopted, scaled, and used by subnational governments to achieve better governance (Canares, 2016).

Also, further research shows that ...our findings show that level of e-participation, population size, the income levels and level of indebtedness of citizens' have an impact on the local governments use of Facebook. High levels of Facebook use would suggest that local governments tend to enable citizens to oversee government making more transparent information, data and processes. Therefore, this study makes a contribution to the debate on local government transparency and provides important guidelines for developing appropriate social media strategies and policies. (Guillamón, Ríos, Gesuele, \& Metallo, 2016).

According to Bachmann (2011), the principle of transparency is synonymous with openness, responsibility, communication ability, management transparency, disclosure of services provided, and the activities of organizations. An inalienable sign of the transparency principle is compliance with generally binding legal regulations and moral values of a company. Breaking the private interests of public officials out of the public interests on the basis of which they were elected. Providing real-time public and substantial information. Handling public funds entails a potential risk of corruption. Control of self-government activities is carried out by public authorities. Exercising decision-making processes entails the risk of corruption, so it's in the interests of the public to start public control of these decision-making processes. It is transparency that allows public control in the areas where publicfunds are spent. Public control is both efficient as well as one of the cheapest means of control, but it only makes sense if it follows the detection of maladministration and public funds management, correction and possible sanctions.

The basic duty of municipalities, selfgoverning communities of citizens, is to provide their citizens with public services and public finance management. Municipal activities affect most citizens, so it is important that municipal decisions that impact everyday life are justified, transparent and reviewable. Observing the transparent behaviour of municipalities contributes to the trust between citizens and their elected authorities. (Morris \& Shin, 2002) state that the quality of the information provided increases the credibility and openness of public institutions, prevents corrupt behaviour and develops the comfort of the municipality's citizens.

The key question is whether Czech Republic citizens actually monitor this information at all and require it.

The international Communicating City Project (Komunikující město, 2000) has brought evidence in the second half of the 1990's on how communication with citizens is useful for city and municipality managements. It was clearly shown, for example that the more public government can inform the public, the more satisfied the citizens are.

Furthermore, the research results regarding the Czech public's views on the state's 2016 information campaign for AKA Company (AKA, 2016), carried out by KANTAR TNS agency, show that most respondents are more interested in local information than in national information. Inhabitants of small municipalities are more interested in local information than inhabitants of large municipalities and cities/towns, although this difference is of no importance.

The presented study focuses on three major research areas:

- The municipality's communication with its citizens - the extent of published information in the municipal office and the municipal events.

- Municipal management and documents on their activities - publishing mandatory information and documents on the municipality's activity.

- Web accessibility - with the following two research questions:

1) What levels are the websites of Czech municipalities?

2) Does the number of inhabitants in the municipality or the region to which the municipality falls, affects the website quality?

The creation of the transparency principle is protected in the Czech Republic's constitutional order and it is shaped by a set of legal regulations which are based on it, international and European law and particularly European Union law. It is the responsibility of each municipality in the Czech Republic to publish and provide information on the basis of applicable legal regulations. Voluntary information publication is 
far more neglected, which is also of valuable character to illustrate activities, cultural and social events in the village. The complete information then strengthens the justification of the municipality leadership, openness and, last but not least, the trust of citizens in the municipal funds economic management.

\section{Defining Transparency}

There are several approaches to the conceptualisation of transparency. Some definitions are descriptive, others are normative. A common denominator of many of those definitions is a belief in information as a sine qua non of transparency (Rawlins, 2008). In a modern society, interlinked concepts related to transparency and governance have been defined: public-sector transparency, government transparency or organisational transparency. Here transparency is therefore perceived as an essential aspect of rationality, progress and good governance (Florini, 2007), and "as a conduct of public affairs in the open or otherwise subject to public scrutiny" (Birkinshaw, 2010). Piotrowski and Van Ryzin (2007) stress the role of transparency. Prat (2006) stresses the control aspects of transparency in organisations using principal - agent model. Here, transparency is the instrument in the hands of principal where it is used to make sure that the agent is acting in line with principal through the delegation of power. Within the given model transparency is an instrument in the hands of the principal, who can use it to make sure that the agent - acting on the behalf of the principal via the delegation of the power - does not promote their own interests instead of those of the principal. When information asymmetry is to the agent's advantage, this may lead to governance abuse and failures. Such problems are believed to be remedied by transparency (Bowles, Hamilton, \& Levy, 2014). Some family resemblance concepts are related to transparency as well - such as openness, insights or clarity (Oliver, 2004). Links between transparency, openness and information are, however, often vague and unclear. One way of explaining the relations is provided by Christensen (2015), when he states that organisational openness may be a precondition for transparency, and information accessibility is seen as a precondition for openness and transparency (Christensen \& Cornelissen, 2015).

\section{Research Methodology}

The research sample consists of 100 Czech municipalities, which were randomly selected from a set of all Czech Republic municipalities with populations ranging between 2,000 to 10,000 inhabitants. The size of the population includes larger municipalities and towns, they have a larger budget and more social and cultural events take place within them. Most municipalities with more than 2,000 inhabitants have over 15 representatives and thanks to this, they elect the municipality government. Each municipality belonging to a defined population has been allocated a number according to the position in the alphabetical order of the municipalities. The numbers representing the municipalities were generated by an online Itnetwork pseudo-random number generator, which was previously tested for the randomness of the generated numbers. Municipalities were randomly generated using assigned numbers, with the condition that at least six municipalities must be selected in each region. The analysed sample is made up of $73 \%$ of municipalities with 5,000 inhabitants, most of which have the status of a town. A one-factor scattering analysis was used to identify the impacts that impact the transparency analysis.

Municipalities with population ranging from 2,000 to 9,999 inhabitants were included in the analysed sample of municipalities, as of 1 st of January 2017, according to the Czech Republic Ministry of the Interior (2017). The selection includes the representation of all regions in the Czech Republic, with the exception of the Capital City of Prague, with the following representation:

- South-Bohemian region - 7 municipalities;

- South Moravian region - 8 municipalities;

- Karlovy Vary region - 7 municipalities;

- Hradec Králové region - 9 municipalities;

- Liberec region - 8 municipalities;

- Moravia-Silesian region - 7 municipalities;

- Olomouc region - 6 municipalities;

- Pardubice region - 7 municipalities;

- Pilsen region - 11 municipalities;

- Central Bohemian region - 11 municipalities;

- Ústí nad Labem region - 6 municipalities;

- Vysočina - 6 municipalities;

- Zlín region - 7 municipalities.

Municipalities are obliged to publish information or documents in a way that allows remote access - which most municipalities resolve with the establishment and operation of websites. The subject of transparency 
research is the provision of mandatory and voluntary information. The municipalities' information obligation in relation to the public is contained in Article 17 paragraph 5 of the Charter of Fundamental Rights and Freedoms, which establishes the constitutional obligation of local authorities to provide information on their activities in a reasonable manner. The conditions and implementation are regulated by Act No. 106/1999 Coll., on free access to information. Decree No. 442/2006 Coll. defines the structure of information published on the municipality in a way that allows for remote access, defines the mandatory published information and its structure. Voluntary information means the publication of the municipality's news, the including inhabitants in discussions regarding the running of the municipality, etc. Municipalities do not have to publish this in-formation, but it is obliged to provide this information on request. However, it is highly recommended to pro-vide such information on a voluntary basis. Therefore, municipalities strengthen citizens' confidence and show that they have nothing to hide.

Based on these pillars, the observation focuses on the following core circuits:

- Municipalities communication with their citizens;

- Management of municipalities and documents on their activities;

- Accessibility of websites.

First area - Municipalities communication with their citizens - focuses on the extent of the published information on the municipal office and the municipal events.

Second area - Management of a municipality and the documents on their activities - focuses on the publication of mandatory information and documents on municipality activities.

Third section - Website accessibility - evaluates the level of orientation and manipulation within the municipality's website. It takes into account the clear arrangement for the general public as well as for citizens with health disadvantages, such as people with poor-vision and the elderly.

The Google search engine was used to find specific municipality websites. Data collection was carried out via the municipalities' websites in January and February 2017.

Each municipality in the selected sample runs its official website. Some of the municipalities have websites accessible only from the micro-region portal, such websites were considered valid as well.

As discussed above, the content analysis is divided into three sub-sections. The following criteria were chosen in the analysis of municipal communication with citizens, which assess whether the municipality publishes the given criterion or not. The criteria include:

- Basic information on the organisational structure of the Office;

- Office hours for the municipal Office;

- E-filing room;

- Budget;

- Strategic plan for municipality development;

- Annual Report;

- Local Newsletter;

- Hobby clubs;

- Non-profit organisations;

- Discussion forum.

Similarly, the following criteria were assessed in the analysis of municipal management and documents on its activities:

- Notification of a procurement/decision;

- Detailed description of the procurement process;

- Full minutes of Council meetings;

- Full minutes of Board meetings;

- Shortened minutes of Council meetings;

- Shortened minutes of Board meetings;

- Who and how they have voted is listed in the Board minutes;

- Who and how they have voted is listed in the Council meetings minutes;

- Voting record available;

- Resolution of the municipal Council;

- Resolution of the municipality Board.

In the last website accessibility analysis, the following criteria were selected:

- Increase font - This doesn't concern an internet browser function.

- Search - With the use of the search box.

- Advanced search - Allows you to define the term with multiple parameters.

- Individuals with poor-sight.

The individual criteria are described and explained in detail in the application part of the thesis.

For a clearer analysis of results, tables, graphs and outputs from the IBM SPSS Statistics 24.0 analytical tool customised are used, which are supplemented with explanatory text.

The following hypotheses have been set: 
$H_{1}$ : The quality of municipal websites do not differ with the municipality size according to the population number.

$\mathrm{H}_{2}$ : The quality of community websites do not differ with the region to which the municipality belongs.

\section{Analysis of Municipalities Communication with Their Citizens}

\subsection{Rate of Compliance with the Obligation to Publish Mandatory and Voluntary Information}

The first analysis examines the extent of compliance with the obligation to publish information on municipalities in a manner allowing for remote access, as prescribed by Act No. 106/1999 on free access to information, obliges municipalities to publish an annual report on their activities for the previous calendar year by $1 \mathrm{st}$ of March at the latest. The structure of the obligatory published information is described in Decree No. 442/2006 Coll. A list of the most important items of the Decree was selected. The examined items include:

- Organisational structure of the Office,
- Office hours,

- Address of e-filling office,

- Municipality budget,

- Strategic plan for municipal development,

- Annual report.

Of the total number of analysed municipalities, only half of them comply with all 6 criteria. However, when we focus only on mandatory information and neglect the recommended publication of the municipal development plan, reach a $73 \%$ success rate. The soothing observation is that each municipality complies with at least part of the given criteria. This analysis was the best of all, its average success rate climbed to satisfying $89 \%$.

In the Fig. 2 we can see how the sample of surveyed municipalities was doing in each category of voluntarily published information. The regular newsletter is issued by $87 \%$ of municipalities. The presence of hobby clubs is in $86 \%$. All municipalities surveyed publish information on their non-profit organisations, which is the only criterion that fills the entire surveyed sample of municipalities and towns. The biggest drop was recorded in the discussion

\section{Fig. 1: Status of mandatory published information}

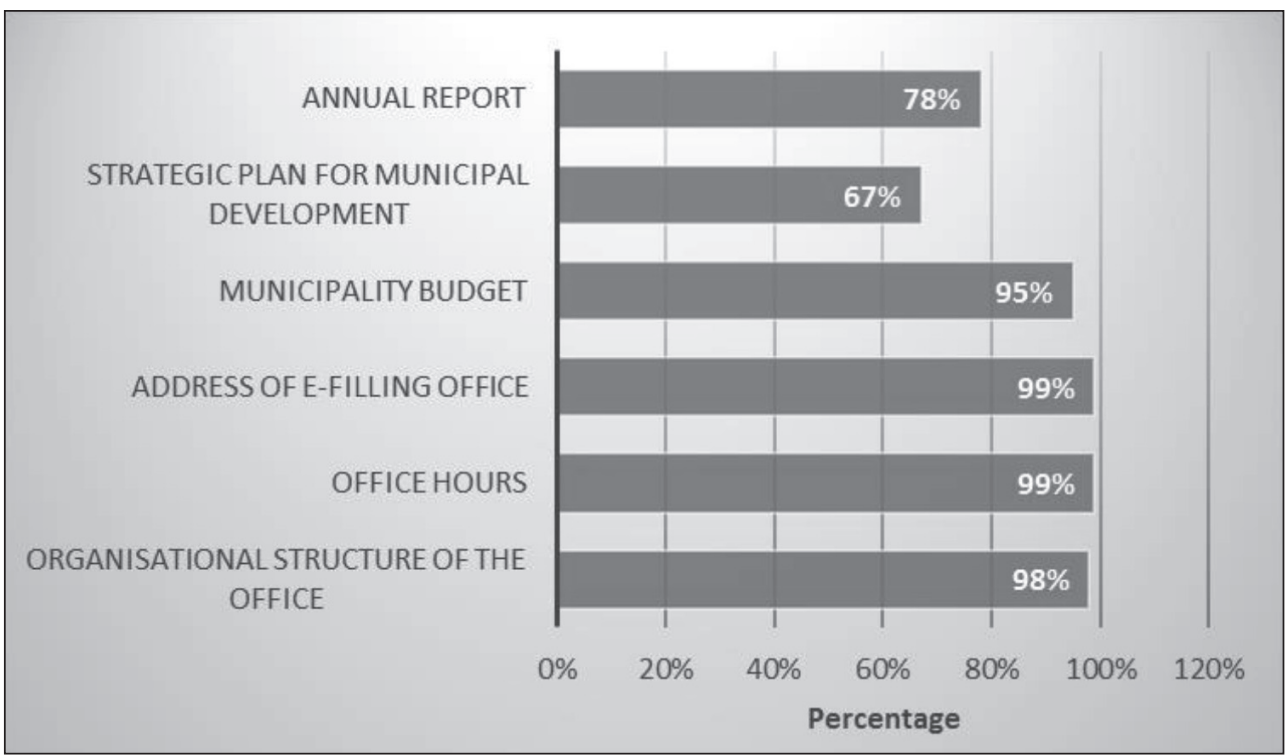

Source: own processing 


\section{Fig. 2: Status of voluntarily published information}

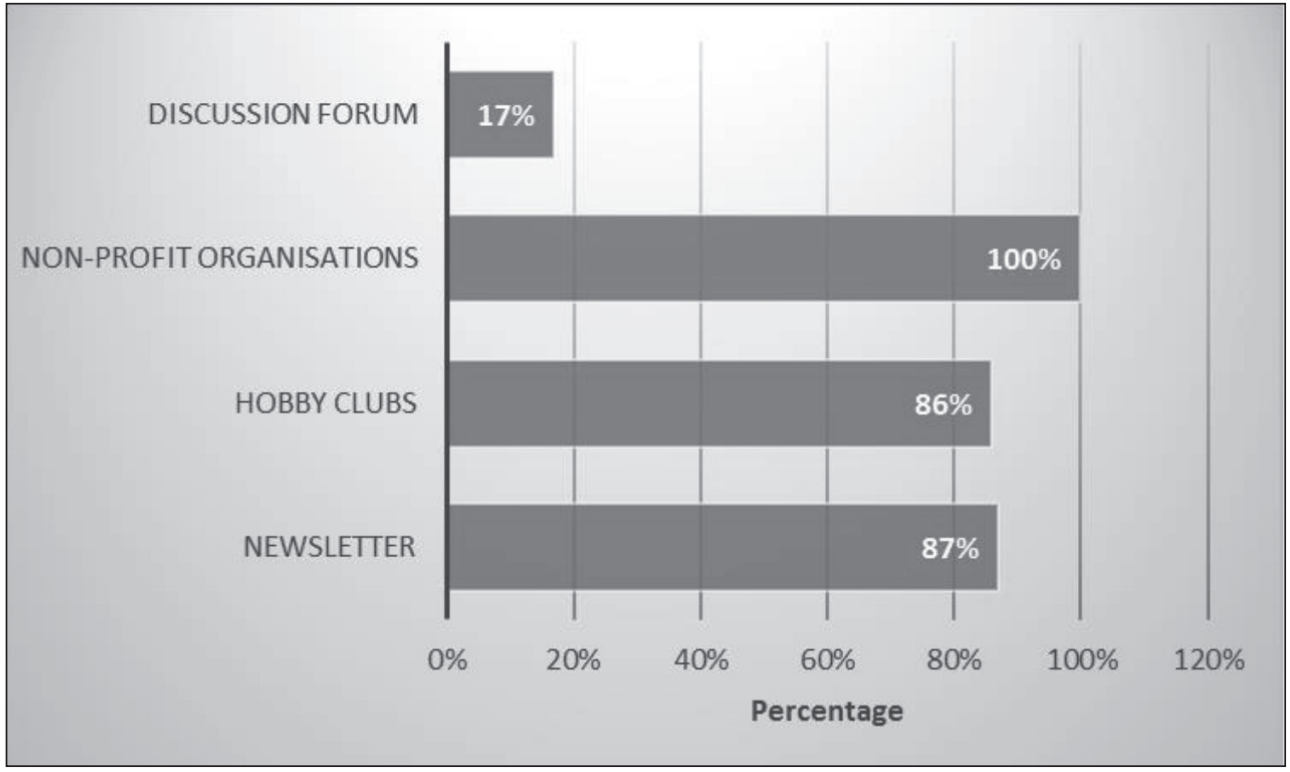

Source: own processing

forum, when only $17 \%$ of municipalities have set them up on their websites.

In this analysis of voluntarily published information of municipalities, $13 \%$ of municipalities did not fail in any aspect and complied with the requirements of the criteria at $100 \%$. As can be seen from the graph above, all of the analysed municipalities succeeded in at least one of the four criteria.

\section{Municipality Management Analysis and the Documents on Their Activities}

\subsection{Information on Public Procurements}

The Public Procurement Act sets out the contracting authority's obligations and procedures in awarding public contracts, which must comply with the principles of transparency and proportionality. The detailed description in Fig. 3 below indicates that the municipality publishes information on the course of the public procurement together with the tender documents necessary for the award procedure. The surveyed municipalities often use external sources for the publication of public procurements, under which the contracting authorities issue public contracts. By referencing an external resource on its website, as part of the analysis it is under-stood as if it was published on its site. Of the surveyed municipalities, $71 \%$ post the announcement of new public procurements on the website together with detailed tender documentation. From this percentage representation of $71 \%$, it should be noted that two thirds of municipalities publish public procurement information through external websites. 13 of the total number of municipalities lack this detailed description. In the case of $16 \%$, the municipalities do not mention the public procurement in any way, nor do they mention any references to external sources.

\subsection{Minutes and Resolutions of the Municipal Council Meeting}

This section examines whether municipalities provide minutes and resolutions on their websites from municipal council meetings. Council meetings are public, so citizens can participate too. A document shall be created from each meeting. The Act on Municipalities 


\section{Fig. 3: The level of information on public procurement}

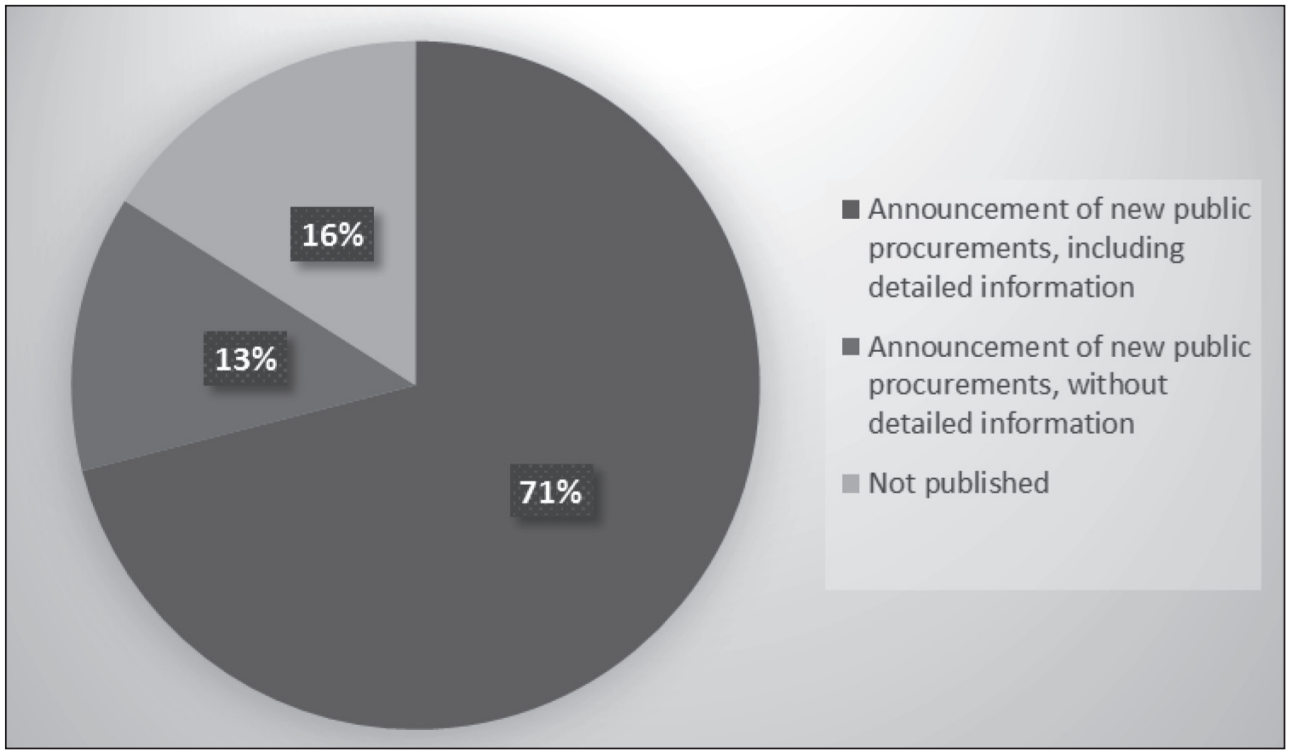

Source: own processing

imposes the necessary elements, which must be fulfilled by the municipal council meeting. They include:

- the number of members present;

- approved session agenda;

- course and outcome of voting;

- adopted resolutions.

In the research, it was assessed whether the municipality published the minutes and if so, whether it contained the mandatory elements listed above. It was found that in the minutes for municipal council meetings, all the municipalities surveyed publish the compulsory entries. As shown in Fig. 4, 58\% of the municipalities do not publish the council meeting minutes.

Municipalities have more opportunities to publish a resolution from a council meeting. The resolution may be part of the $m$ municipality meeting minutes or as a separate document in which the resolutions adopted are listed. Another option is the combination of the two previous ones, the municipality then issues two separate documents, which contain more detailed information on the agenda of the meeting and the resolution as well as the resolution as a separate document.
Fig. 5 shows that $96 \%$ of the municipalities publish a resolution of the council meeting in one of these ways. It was not possible in only $4 \%$ to find any resolution. In more than half of the cases, municipalities only pub-lish the resolution as a separate document. $25 \%$ of municipalities list the resolution as part of the meeting minutes and in $18 \%$ the resolution is published in the minutes and also as a separate municipality document.

\subsection{Municipal Council Meetings Minutes and Resolutions}

In a sample of 100 municipalities, there are those who do not have council in their office administration. These are municipalities where less than 15 representatives have been elected to the office. $12 \%$ of municipalities in the sample didn't elect and doesn't have a council. As a result, the assessment of publishing municipal council meetings minutes and resolutions couldn't be carried out. The Act on Municipalities stipulates, as in the case of a council meeting, the necessary points of the municipal council minutes. These include:

- the number of members present; 


\section{Fig. 4: Rate of published municipal council meetings minutes}

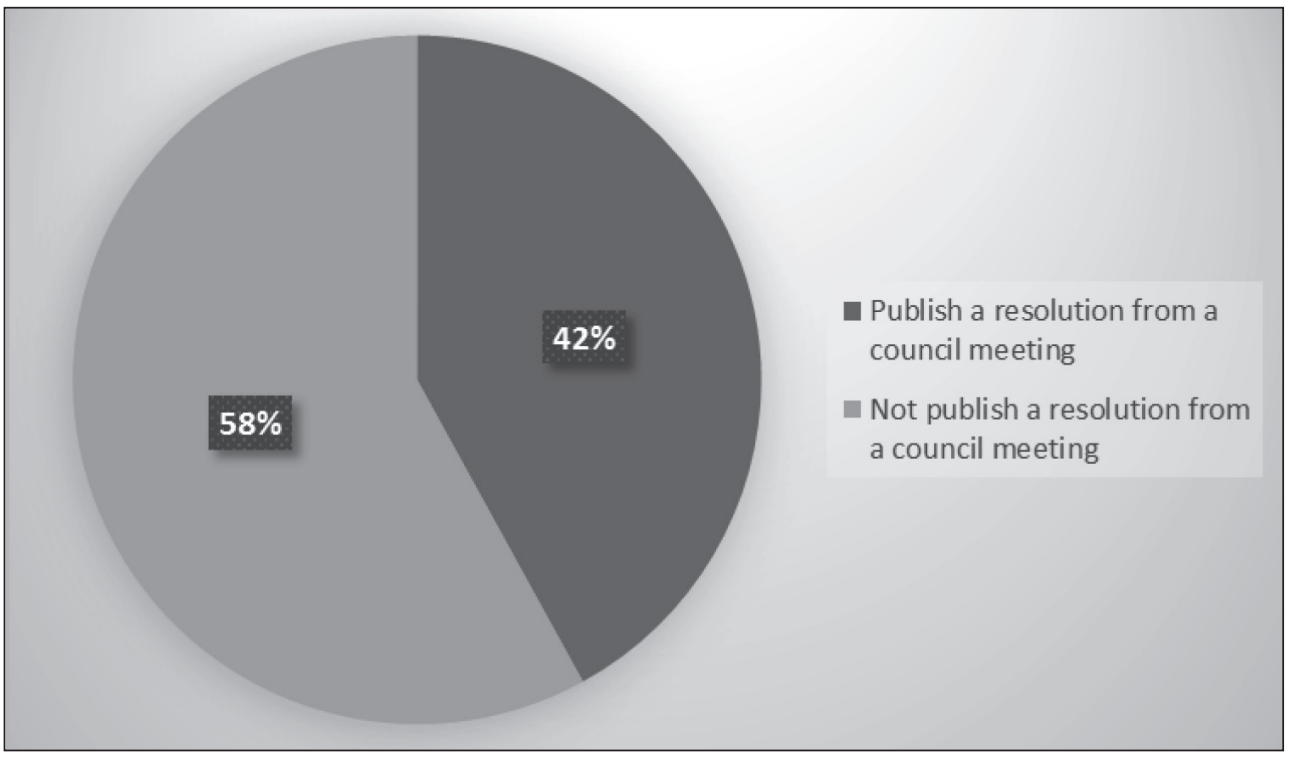

Source: own processing

\section{Fig. 5: The extent of published resolutions from municipal council meetings}

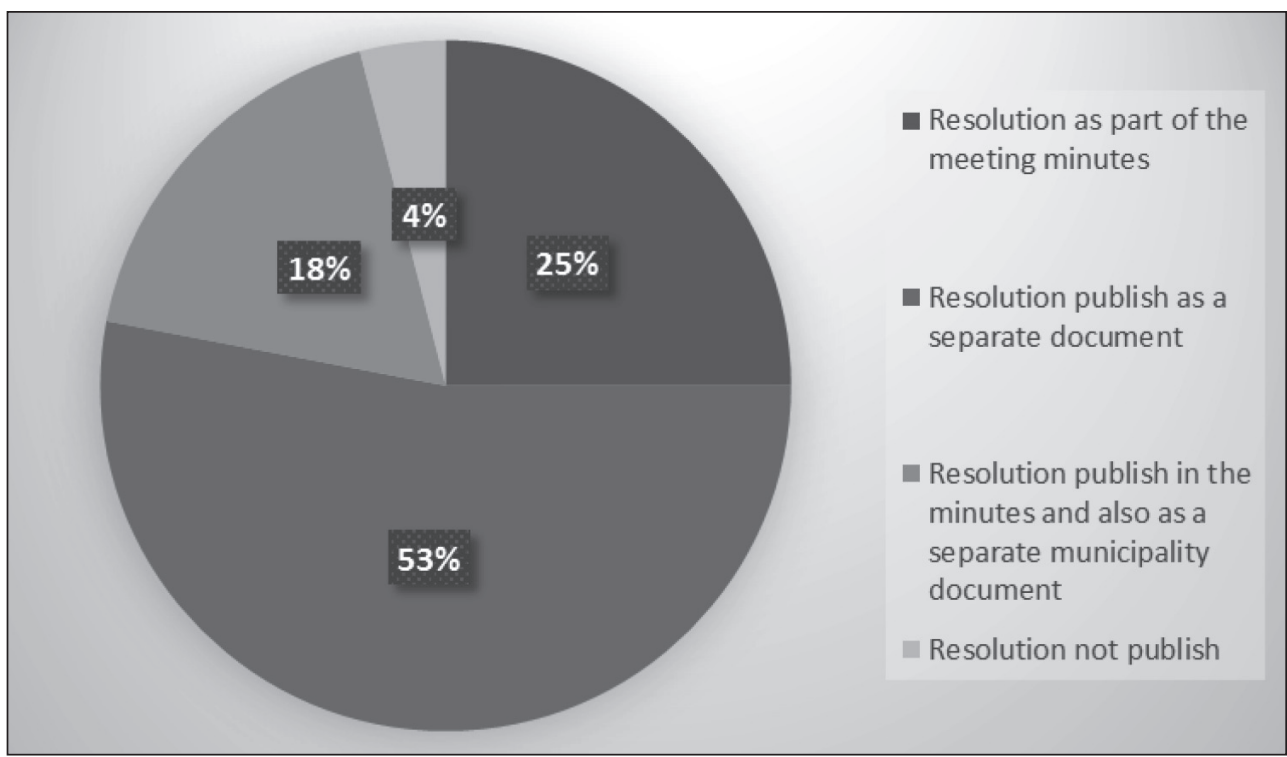

Source: own processing 
- approved meeting agenda;

- course and outcome of voting;

- adopted resolutions.

Municipal council meetings are not public, so publishing the minutes can be considered as essential for determining how the municipality council manages the administration of the municipality and with the municipal issues. Publication of council meetings minutes is not as popular with municipalities as in the case of minutes of the board meetings. All the investigated municipal council meetings minutes fulfilled the content obligations according to the Act on Municipalities. However, only $15 \%$ of them publish total minutes on the website.

The situation under examination is again identical with the consideration of the municipal council meeting resolution. The resolutions were posted as a separate document, as part of the council minutes, or a combination of the two.

Again, as in the case of resolution of the board meeting, we can see that the largest case of publication was the publication of the municipal council meeting resolution in the form of a separate document, i.e. $62 \%$ of the municipalities publish in this way. $10 \%$ of the municipalities publish the council's resolution within the minutes. A small number of municipalities $(5 \%)$, decided to choose the combinations of previous cases. $11 \%$ of municipalities do not publish any mention of the municipality council meetings resolution, although they have a council.

\subsection{Minutes - Who Voted and How}

With the formation of the council meetings minutes, the municipality is obliged to state the voting result. A properly graded report should also include a list of council members/councillors with the details of who and how voted for each item. Just so, the citizens (voters) can find out if the elected municipal administrators act honestly and fulfil their pre-election promises. Votes percentage are calculated from the total number of published minutes; in the case of minutes from council meetings, it is from a total of 42 minutes; in the case of board meetings minutes it is from a total of 15 minutes.

More than half of the municipalities (57\%) publish who voted and how they voted on the website, listing the municipal council meeting minutes.

\subsection{Record of the Municipal Council Meeting}

Municipal council meetings are not public, according to the Act on Municipalities. Therefore, examination of publishing the records of the municipal council meetings was carried out only at the municipal council meeting. The assessment was divided into the publication of audio or video recordings. Some of the municipalities publishing records for municipal council meetings were not available for viewing directly on the municipality's site but through a link. This fact is given the same weight as if the municipality publish the record on its website. Posting records from the meetings of municipalities enables citizens to also see the council meeting after the time it took place. It's possible to watch the video repeatedly from anywhere you have an internet connection. It is further confirmation from the municipality that it has nothing to hide and its administration is transparent. Most municipalities do not use the possibility of publishing the council meetings minutes. The percentage is $87 \%$. The video recordings of council meetings is published by $9 \%$ of the municipalities and the remaining $4 \%$ of municipalities make audio recordings available.

In the second analysis of the municipalities' management and documents on their activities, none of the municipalities succeeded in all criteria, which can be attributed to its larger content and also the fact that none of the criteria in the second analysis gives the municipalities the legal obligation to publish these facts. We can-not say that this analysis was not successful. With the loss of one point out of a total of 9 , two municipalities fulfilled all the other criteria.

\section{Analysis of Website Accessibility}

The third part of the analysis focuses on the accessibility of websites. The accessibility of websites means an intuitive layout of important elements, easy orientation on the municipality website and the ability to search for the required information. Website searching is largely facilitated by a search engine and an advanced search form, which allows you to more specific search data. Another requirement for accessible pages is the possibility of enlarging the font (without using the internet browser features). It helps visually impaired users to intuitively adjust the size of the display 


\section{Fig. 6: Website accessibility status}

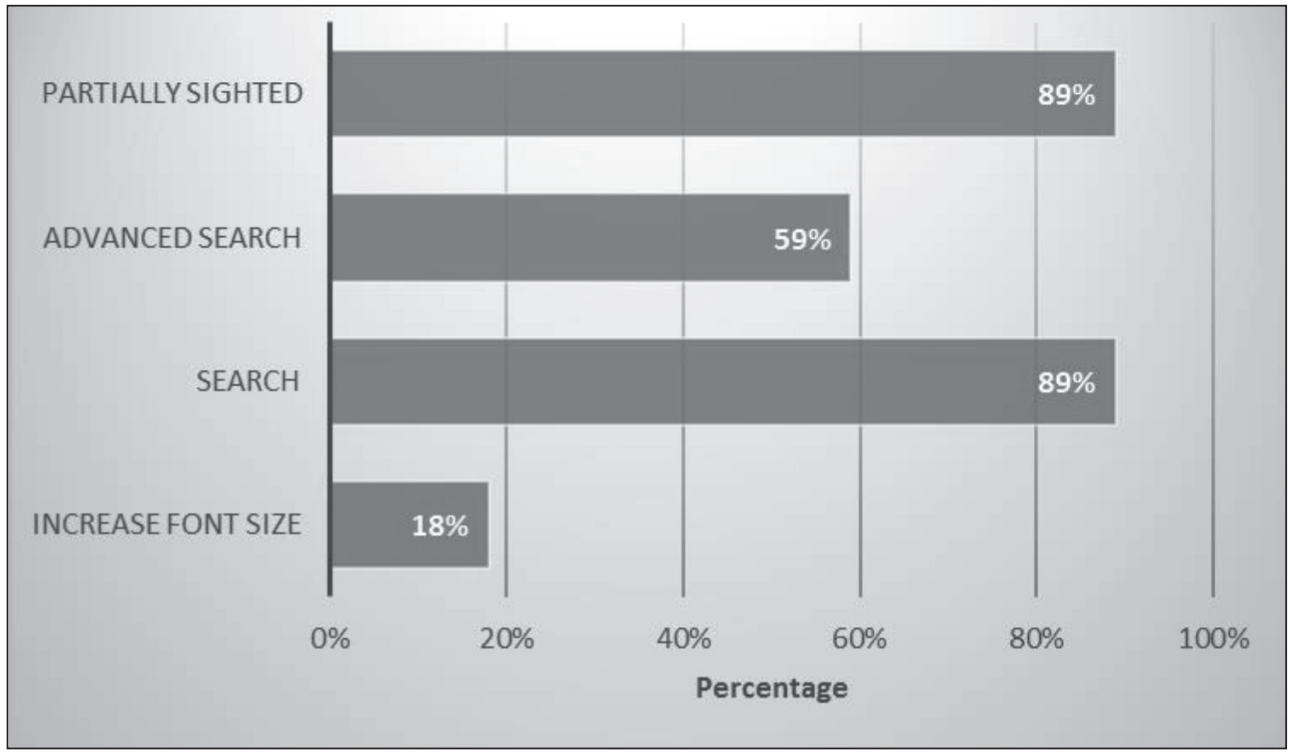

Source: own processing

text. Another option for web presentations of individual municipalities was to switch to a simplified form of display. The simplified version of the pages is redesigned to a text design and cascading styles are disabled. The simplified form of websites makes internet presentations also available to health disadvantaged users. This simple style change option is provided by $55 \%$ of webpages.

Fig. 6 shows that $89 \%$ gives users the ability to search for information through search engines in the case that advanced search is less than $60 \%$. Only $18 \%$ of municipalities can make the font smaller directly through their websites.

Of the total sample of municipalities, only one fifth of them meet all of the partial accessibility analysis criteria.

\subsection{Factors Affecting the Quality of Websites}

The third part of the analysis focuses on the accessibility of websites. The accessibility of website means an intuitive layout of important elements, easy orientation on the municipality website and the ability to search for the required information. The search engine and advanced search form largely facilitate searching through the websites, which allows you to search data more specifically. Another requirement for accessible pages is the possibility of font enlargement (without using the Internet browser features). It helps visually impaired users to intuitively adjust the size of the displayed text. Another option for individual municipalities' web presentations was to switch to a simplified form of display. The simplified version of the pages is redesigned and cascading styles are disabled. The simplified form of websites also make internet presentations available to disadvantaged users. This simple style change option is offered by $55 \%$ of pages.

The barrier-free access of the municipalities' sites is governed by Decree No. 64/2008 Coll. on the accessibility of websites of public authorities, each municipality is obliged to make information available on its activities to people with disabilities, in accordance with this decree in a way allowing remote access. Rules established by the Methodological Guideline on Decree No. 64/2008 Coll. were developed on the basis of the WCAG 1.0, Section 508 and Blind Friendly Web methodologies (The 
Czech Republic Ministry of Interior, 2010). The website accessibility in the Czech Republic is dealt by the Blind Friendly Web project (hereinafter referred to as BFW), which sets out methodological guidelines for creating accessible sites for disabled people and helps in their implementation.

According to the Methodology of Blind Friendly Web 2.3 (Pavlíček, 2005), a quick check of the accessibility of website checked the municipality websites. Webpages can be viewed as fully readable and comprehensible in $99 \%$ of all websites under review - the criterion for visually impaired individuals, see Fig. 6 . Most webpages can be marked as accessible to visually impaired users.

\section{Results}

The aim of the analysis was to assess how the Czech municipalities do in keeping with the principle of transparency on their websites. The analysis was divided into three sub-sections:

1. Communications of municipalities with citizens where the publication of mandatory and voluntary in-formation has been investigated;

2. The management of municipalities in the field of public procurement and the publication of documents related to their activities, such as minutes and resolutions from meetings of municipal councils and boards and their particulars;

3. Accessibility of websites to facilitate orientation and the retrieval of information on websites, more accessible use of websites for visually impaired users as well as the elderly.

The results of each partial analysis were different. The first analysis of municipalities' communication with citizens was very good, where the overall rating is an $81 \%$ success in publishing the information under re-view. The least successful was compliance with the discussion forum criteria on municipality websites. The criteria for the mandatory disclosure of information also rated very well. All 12 municipalities, from the sample of 100 municipalities surveyed, met all the criteria in this analysis. It should be mentioned that half of the most successful municipalities in the first analysis have a population ranging between 5,000 and 9,999 , only $27 \%$ of the total number of municipalities surveyed is in this size category.
The evaluation of the analysis dealing with the accessibility of the website ended up slightly worse. Its success rate is $66 \%$. The criterion of font size change was the least fulfilled. On the contrary, the criterion for visually impaired individuals ended up the best. Despite the decline in success in the accessibility analysis, the number of municipalities fulfilling all the criteria of this analysis increased to 20 successful municipalities. Of these 20 municipalities, a total 14 belong to group size ranging between 2,000 and 5,000 inhabitants. Municipalities ranging between 2,000 and 5,000 inhabitants account for approximately $70 \%$ of the sample surveyed.

The worst part of the analysis was the part analysing municipalities' management and documents on their activities. Its success reaches only $49 \%$. The criterion examining the publication of the resolution from municipal councils meetings, which achieved a $96 \%$ success in this analysis, was the most successful. None of the municipalities managed to meet all the criteria examined. The reason for this may be the difficulty from the point of view of the voluntarily provided information. Two municipalities have failed to meet only one criterion.

In the work, the factors that could influence the quality of the municipalities' websites were examined through a one-factor analysis of scattering.

Within the testing of both hypotheses, it was first necessary to verify that random samples were from a normal distribution. This was verified by the combination of the Liliefors variant of the Kolmogor-Smirnov test and the Shapiro-Wilk test. Furthermore, homogeneity of scatterings (homoscedasticity) was also tested. Homoscedasticity was numerically tested using the Brown-Forsythe test. At the significance level of $5 \%$, with both hypotheses the normality and homogeneous scattering tests cannot be rejected.

Two hypotheses were identified and examined.

$\mathrm{H}_{1}$ : The quality of municipal websites does not differ with the size of municipalities by population. (test statistic $F$ has a value of 1.919 , the corresponding $p$-value is 0.152 , at a significance level of 0.050; at the significance level of $5 \%$ it was proved that the mean values of municipalities are not different in different groups of municipalities) - we do not reject the hypothesis 
$\mathrm{H}_{2}$ : The quality of the municipal website does not differ regarding the region to which the municipality belongs. (the tested statistic $F$ has a value of 0.946 and the $p$-value is 0.506 , at the significance level of 0.050) - we do not reject the hypothesis

Both of these hypotheses were not rejected after the calculations carried out. This means that the quality of municipal websites of individual municipalities does not depend on the number of inhabitants in individual municipalities or on the region where the municipalities are located.

The overall results of the analysis of compliance with the principle of transparency on the municipalities' websites in the Czech Republic are quite satisfactory. Most municipalities surveyed provide basic information and their webpages are also accessible to disadvantaged clients. The municipalities publish the documents on their activities less often. The overall summary of the research results has risen to a $65 \%$ success rate of the surveyed municipalities. This means that $65 \%$ of municipalities are concerned with open disclosure of information. As Šolc (2014) states, the conscious municipalities don't wait for the legislation to be tightened, but publish everything that can be published on their websites voluntarily. From the total number of 100 municipalities surveyed, none of them complied with all evaluation criteria divided into three logical units. On the other hand, at least in one partial analysis, 32 municipalities succeeded and publish all the information surveyed, which makes up one third of the sample municipalities. This is more than twice the value compared to the resulting value based on research in my Bachelor Thesis. I evaluate it very positively, but there is still a large area for future improvement in the field of publicity on the municipality websites.

The results of the analyses clearly show that if the legislation in force obliges municipalities to publish specific information in a way that allows remote access, the municipalities' efforts to fulfil these regulations will increase rapidly. It is an open and responsible action for municipalities, which helps to create an anticorruption environment of municipalities and therefore increases the possibility of citizens' involvement as a tool for public control.

Limiting research limits is the fact that 100 Czech municipalities with population ranging between 2,000 and 9,999 were surveyed. This research sample of 100 municipalities accounts for $18 \%$ of the size group of municipalities on 1 st of January 2016. $21 \%$ of the Czech Republic's population live in places sized between 2,000 and 9,999 inhabitants. The research sample consists of 73 municipalities with up to 5,000 inhabitants. These are larger municipalities, which in most cases have the status of a town, in a total of 72 cases.

\section{Discussion and Conclusion}

Czech municipalities have been heterogeneous in the analysis of digital transparency. Once the legislation precisely defines the scope and form of mandatory disclosure of information on municipalities' websites, there is a great deal of improvement and the efforts of municipalities to fulfil this obligation. The degree of disclosure is decreasing with the freedom for municipalities to publish information. Legislation generally intends to support the openness manifestations of municipalities, but transparent behaviour depends on each municipality. As a suitable approach, it is advisable to define the specification of the requirements more clearly for a way allowing remote access in Czech legislation. Another procedure could be to introduce other legislation that would capture this issue better on the whole. Despite gradual improvements in the quality of the municipality websites, there are still major issues lacking that need to improve.

We are inclined to the opinion of Scott (2006), he states that websites provide the most basic public services and citizens are therefore more connected with the government. Web content and its usage requirements are constantly increasing. Municipalities must monitor and enhance the quality of their websites regularly to at-tract and satisfy users (Scott, 2006).

In order to improve the quality of municipalities' web content, specialised web portals can contribute and serve as help counsellors. They often help to point out the issues and come up with an inspirational solution. An example is the Open Society Strengthening Civic Society in the Czech Republic or Transparency International.

Acknowledgments: The paper was written with the support of the specific project 6/2017 grant "Determinants affecting job satisfaction" 
granted by the University of Hradec Králové, Czech Republic and thanks to help of student Šárka Jelínková.

\section{References}

AKA. (2016). Výzkum zájmu veřejnosti o informace. Retrieved from http://www. mediar.cz/wp-content/uploads/2017/03/zajemverejnosti-o-informace-aka-tns-kantar-2016.pdf.

Araujo, J. F. F. E. de, \& Tejedo-Romero, F. (2016). Local government transparency index: determinants of municipalities' rankings. International Journal of Public Sector Management, 29(4), 327-347. doi:10.1108/ IJPSM-11-2015-0199.

Bachmann, P. (2011). Factors Determining Quality of Municipal Web Site. In Liberec Economic Forum. Liberec: Technická univerzita Liberec. Retrieved from http://www.lef-tul.cz/ sekce/LEF_2011.pdf.

Bannister, F., \& Connolly, R. (2011). The Trouble with Transparency: A Critical Review of Openness in e-Government. Policy \& Internet, 3(1), 158-187. doi:10.2202/1944-2866.1076.

Bennis, W. (2013). Leadership in a Digital World: Embracing Transparency and Adaptive Capacity. MIS Quarterly, 37(2), 635-636.

Birkinshaw, P. (2010). Freedom of information: the law, the practice, and the ideal (4th ed.). Cambridge, New York: Cambridge University Press.

Bowles, N., Hamilton, J., \& Levy, D. A. L. (Eds.). (2014). Transparency in politics and the media: accounta-bility and open government. London, New York: I. B. Tauris \& Co. Ltd., in association with the Reuters Insti-tute for the Study of Journalism, University of Oxford.

Canares, M. P. (2016). Creating the Enabling Environment for More Transparent and Better-resourced Local Governments: A Case of E-taxation in the Philippines. Information Technology for Development, 22(sup1), 121138. doi:10.1080/02681102.2015.1121857.

Christensen, L. T., \& Cornelissen, J. (2015). Organizational transparency as myth and metaphor. European Journal of Social Theory, 18(2), 132-149. doi:10.1177/1368431014555256.

Český statistický úradad. (2015). Malý lexikon obci České republiky - 2016. Retrieved January 10, 2017, from https://www.czso.cz/csu/czso/ maly-lexikon-obci-ceske-republiky-2016.

Florini, A. (Ed.). (2007). The Right to Know: Transparency for an Open World. New York Chichester, West Sussex: Columbia University Press. doi:10.7312/flor14158.
Guillamón, M.-D., Ríos, A.-M., Gesuele, B., \& Metallo, C. (2016). Factors influencing social media use in local governments: The case of Italy and Spain. Government Information Quarterly, 33(3), 460-471. doi:10.1016/j.giq.2016.06.005.

Komunikující město. (2000). Retrieved from www.komunikujici-mesto.cz.

Ministerstvo pro místní rozvoj. (2017). Metodika $k$ vyhlášce o uveřejňování formulářu proúčelyzákonaozadáváníveřejných zakázeka náležitostech profilu zadavatele. Retrieved from https://www.portal-vz.cz/getmedia/0d646e5fd960-4743-b5b3-e885dcab7b1c/Metodika-kvyhlasce-o-uverejnovani-a-profilu-zadavatele_ v4-bez-registrace_duben-2017.pdf.

Ministerstvo vnitra České republiky. (2010). Metodický pokyn k vyhlášce č. 64/2008 Sb., o formě uveřejňování informací souvisejících $s$ výkonem veřejné správy prostřednictvím webových stránek pro osoby se zdravotním postižením (vyhláška o přistupnosti). Retrieved from http://www.mvcr.cz/clanek/ metodicky-pokyn-k-vyhlasce-c-64-2008-sb-oforme-uverejnovani-informaci-souvisejicichs-vykonem-verejne-spravy-prostrednictvimwebovych-stranek-pro-osoby-se-zdravotnimpostizenim-vyhlaska-o-pristupnosti.aspx.

Ministerstvo vnitra České republiky. (2017). Počty obyvatel v obcích. Retrieved from http:// www.mvcr.cz/clanek/statistiky-pocty-obyvatelv-obcich.aspx.

Morris, S., \& Shin, H. S. (2002). Social Value of Public Information. American Economic Review, 92(5), 1521-1534. doi:10.1257/000282802762024610.

Oliver, R. W. (2004). What is transparency? New York: McGraw-Hill.

Pavlíček, R. (2005). Dokumentace zásad prístupnosti webových stránek pro uživatele $s$ těžkým zrakovým postižením (metodický návod pro tvůrce webů). Retrieved from http://www. blindfriendly.cz.

Piotrowski, S. J., \& Van Ryzin, G. G. (2007). Citizen Attitudes Toward Transparency in Local Government. The American Review of Public Administration, 37(3), 306-323. doi:10.1177/0275074006296777.

Prat, A. (2006). The More Closely We Are Watched, the Better We Behave? In C. Hood, \& D. Heald (Eds.), Transparency: The Key to Better Governance? (pp. 91-103). British Academy. doi:10.5871/bacad/9780197263839.003.0006.

Rawlins, B. (2008). Give the Emperor a Mirror: Toward Developing a Stakeholder 
Measurement of Organiza-tional Transparency. Journal of Public Relations Research, 21(1), 71-99. doi:10.1080/10627260802153421.

Scott, J. K. (2006). 'E' the People: Do U.S. Municipal Government Web Sites Support Public Involvement? Public Administration Review, 66(3), 341-353. doi:10.1111/j.15406210.2006.00593.x.

Sičáková-Beblavá, E., Kollárik, M., \& Sloboda, M. (2016). Exploring the Determinants of Transparency of Slovak Municipalities. NISPAcee Journal of Public Administration and Policy, 9(2). 121-145. doi:10.1515/ nispa-2016-0017.

Strathern, M. (2000). The Tyranny of Transparency. British Educational Research Journal, 26(3), 309-321. doi:10.1080/713651562.

Pavlíček, R. (2005). Metodika Bind Friendly Web 2.3. Blind Friendly. Retrieved from http:// blindfriendly.cz/metodika\#kap5.

Šolc, J. (2014). Chytrá města a obce informatika nejen pro lepší úradování, ale také pomocník pro samosprávu. Retrieved April 12, 2017, from http://denik.obce.cz/clanek. asp? $\mathrm{id}=6677579$.

Transparency International. (nd). Územní samospráva. Retrieved from https://www. transparency.cz/pravni-poradna/uzemnisamosprava/.

Vyhláška č. 64/2008 Sb., o formě uveřejňování informací souvisejících s výkonem veřejné správy prostřednictvím webových stránek pro osoby se zdravotním postižením (vyhláška o přístupnosti).

Vyhláška č. 442/2006 Sb. Vyhláška, kterou se stanoví struktura informací zveřejňovaných o povinném subjektu způsobem umožňujícím dálkový př́stup.

Zákon č. 1/1993 Sb., Ústava České republiky.

Zákon č. 2/1993 Sb., Listina základních práv a svobod čl. 17.

Zákon č. 14/2017 Sb., kterým se mění zákon č. 159/2006 Sb., o střetu zájmů, ve znění pozdějších předpisů, a další související zákony.
Zákon č. 85/1990 Sb., o právu petičním (petiční zákon).

Zákon č. 101/2000 Sb., o ochraně osobních údajů a o změně některých zákonů (zákon o ochraně osobních údajů).

Zákon č. 106/1999 Sb., o svobodném prístupu k informacím (zákon o svobodném prístupu).

Zákon č. 123/1998 Sb., o právu na informace o životním prostředí.

Zákon č. 128/2000 Sb., o obcích (zákon o obcích).

Zákon č. 134/2016 Sb., o zadávání veřejných zakázek.

Zákon č. 148/1998 Sb., o ochraně utajovaných skutečností a o změně některých zákonů.

Zákon č. 159/2006 Sb., o střetu zájmů.

Zákon č. 227/2000 Sb., o elektronickém podpisu a o změně některých dalších zákonů.

Zákon č. 349/1999 Sb., o Veřejném ochránci práv.

Zákon č. 491/2001 Sb., o volbách do zastupitelstev obcí (zákon o komunálních volbách).

Zákon č. 500/2004 Sb., správní řád.

Zákon o zadávání veřejných zakázek. (nd). [Online]. Dostupný 10. duben 2017, z Profil zadavatele, váš el-ektronický nástroj: https://www. profilzadavatele.cz/zakon-134-ozadavani-zakazek/.

doc. Ing. Hana Mohelská, Ph.D. University of Hradec Králové Faculty of Informatics and Management Department of Management hana.mohelska@uhk.cz

doc. Ing. Marcela Sokolová, Ph.D. University of Hradec Králové

Faculty of Informatics and Management Department of Management marcela.sokolova@uhk.cz 


\section{Abstract}

\section{DIGITAL TRANSPARENCY IN THE PUBLIC SECTOR - CASE STUDY CZECH REPUBLIC}

\section{Hana Mohelská, Marcela Sokolová}

The subject of the paper is to carry out evaluation of the current information openness of municipalities through the structured observation method, via their web pages. The aim of the paper is to assess the transparency level of municipalities in the Czech Republic. It focuses on the lawful and voluntary publication of in-formation on the websites of randomly selected group of municipalities. The content analysis on the internet was used. The thesis focuses on qualitative and quantitative data acquisition as the most effective combination. The research sample consists of 100 municipalities, which were randomly selected from a set of all municipalities in the Czech Republic with populations ranging between 2,000 to 10,000 inhabitants. The paper's introductory part defines the basic concepts and obligations, which are laid down to the municipalities by international and especially Czech legislation. It is followed by the analysis of selected municipalities on the Internet, which is divided into municipalities' management and documents regarding their activities, the office's communication with its citizens and accessibility of the sites. A synthesis of findings presents the most transparent municipalities and regions. Czech municipalities have been heterogeneous in the analysis of digital transparency. Once the legislation precisely defines the scope and form of mandatory disclosure of information on municipalities' websites, there is a great deal of improvement and the efforts of municipalities to fulfil this obligation. The degree of disclosure is decreasing with the freedom for municipalities to publish information. The conclusion of the paper is devoted to the overall assessment and recommendations for the given situation in the Czech Republic.

Key Words: Digital transparency, public sector, research, Czech Republic.

JEL Classification: H79, R58.

DOI: 10.15240/tul/001/2017-4-016 